\title{
ТЕМАТСКА АНАЛИЗА: ОСВРТ КОН МОЖНОСТИТЕ ЗА ЕВАЛУАЦИЈА НА КВАЛИТЕТОТ НА ИСТРАЖУВАњЕТО
}

\section{Кратка содржина}

Тематската анализа е широко употребуван метод на анализа во психолоиките истражувања, како во оние кои се примарно квалитативни, така и во оние кои го комбинираат квалитативниот и квантитативниот пристап. Трудот накусо се осврнува на тоа ито претставува тематската анализа и како се користи во рамките на различни епистемолошки и онтолошки позищии, објаснувајќи ги главните карактеристики на различните видови тематска анализа кои се користат. Потоа, дискутирајки ја неопходноста од преиспитување на прочесот на анализа на систематски начин, ги објаснува стартегиите кои треба да се преземат за да се обезбеди повторливост (релијабилност) и кредибилност (валидност) на наодите генерирани со овој пристап. Текстот завриува со издвојување на некои од предностите и слабостите на тематската анализа, заедно со сугерирани критериуми за одлучување во кои случаи овој метод е најсоодветно решение за анализа и интерпретачија на податочите. Заклучено е дека иако е многу корисна, тематската анализа, поради нискиот степен на интерпретативност, не е соодветна за одговарање на истражувачки прашања кои барат поголема фокусираност на даден аспект или правење фини разлики меѓу различни групи испитаници.

Клучни зборови: ТЕМАТСКА АНАЛИЗА, КВАЛИТАТИВНИ ИСТРАЖУВАњА, КРЕДИБИЛНОСТ

Тематската анализа е метод за откривање и соопштување обрасци и теми во рамки на податоците, кој може да оди и подалеку од нивно опишување, односно, дозволува впуштање во интерпретација на идентификуваните теми (Braun \& Clarke, 2006; 2013). Едно скорешно истражување за доминацијата на пристапи во квалитативните студии, на податоци црпени од социјалните медиуми, открива дека тематската анализа, на која се реферира и како на анализа на содржина, е најкористениот метод на анализа во квалитативните нацрти за истражувањата објавени меѓу 2007 и 2013 година (Snelson, 2016). Уште почесто, таа претставува метод на избор за квалитативна анализа во комбинираните квантитативно-квалитативни нацрти. Популарноста на методот се должи на неколку причини. Едната е дека тематската анализа е мошне флексибилна од перспектива на епистемолошката платформа, бидејќи може да се изведе и од позиција на есенцијализам (реализам), за да се соопштат доживеаните искуства, настани и гледишта на испитаниците, и од позиција на конструктивистичката парадигма, за да се истражи на кои општестве- 
ни дискурси овие искуства и гледишта се последица. Втората причина е дека таа може да се третира како генерички пристап во анализирањето податоци бидејќ не е нужно да се врзе за ниту една конкретна теориска ориентација (Buetow, 2010; Percy, Kostere \& Kostere, 2015). Тоа истовремено значи и дека совладувањето на техниката на анализа не бара специфична обука во рамки на одредена школа, како што се, на пример, феноменологијата, хевриситиката или херменевтиката. Оттука, претставува идеално решение за истражувачите кои, главно, се потпираат на квантитативна методологија, секогаш кога квалитативната анализа се прави за дополнување на квантитативните наоди, или за првичен увид во појавите пред започнување на квантитативните студии. Дополнително, тематската анализа дозволува обработка на податоците која на континуумот дескрипција - интерпретација стои многу повеќе накај екстремот кој не бара интерпретативни елементи (Sandelowsky, 2010), што го прави овој метод дополнително соодветен за комбинираните истражувања и за истражувачите кои не се експерти во квалитативната методологија. Третата причина, која делумно произлегува од претходната, исто така, не е помалку релевантен фактор за честото користење на тематската анализа. Бојаsис (Boyatzis, 1998; стр. 4) заблежува дека тематската анализа „не претставува уште еден квалитативен метод, туку е процес кој може да биде користен со повекето, ако не и со сите, квалитативни методи“. Со други зборови, пристапот е парадигматичен од аспект на чекорите кои се преземаат за да се организира и осмисли квалитативниот материјал кој треба да се анализира, без разлика на тоа во која интерпретативна рамка понатаму ќе се смести. Оттука, на совладувањето на стратегијата во обработка на податоците која ја бара тематската анализа може да се гледа како на прагматичен чекор, затоа што е идеална основа и за стекнување понатамошни компетенции во теориски заснованите начини на анализирање квалитативен материјал.

Несомнено е дека голема предност на овој метод е и едноставноста во примената и ефикасноста од аспект на заштеда при дополнителна обука која вообичаено е неопходна кога се практикува анализа од перспектива на методите кои произлегуваат од дефинирани теориски пристапи или ориентации. Истовремено, важно е да се нагласи дека оваа предност може да биде и опасна стапица. Прегледот на истражувања во кои податоците се анализираат со помош на тематска анализа како генерички пристап сугерира дека авторите преземаат многу малку, или речиси воопшто не преземаат мерки за докажување на квалитетот на добиените наоди од перспектива на нивна релијабилност и валидност. Со оглед на важноста на ова прашање, кое неретко се занемарува во замена за богатството детали кое го обезбедува пристапот, а поради што кон квалитативниот метод во целина се упатуваат жестоки критики, овој текст ќе се задржи токму на прегледување и дискутирање на начините на кои тоа може (и би требало) да се направи.

\section{Чекори во процесот на изведување тематска анализа}

Изведувањето на тематската анализа бара сериозни напори, толеранција кон неизвесност, креативност, критичност и веројато, пред сѐ, трпеливост. Аналитичарот, по правило соочен со огромни количества пишан материјал, може да из- 
бере неколку стратегии при издвојување на темите од сировите податоци, но што и да одлучи да преземе, не може да ги избегне итерациите во препрочитување на податоците и повторените трансформации на веќе изведените кодови. Не постои ситуација за која не може да се каже дека првичната организација на кодираниот материјал повеќе претставува потенцијална структура отколку конечно решение. Отсуството на ригидни правила за тоа како да се изведе анализата е дополнителен предизвик. Затоа, при правењето на тематската анализа, се препорачува постојано поставување прашања кои Patton (2002) често ги нарекува сензитизирачки, а на кои може да се гледа како на алатки за структурирање на процесот: Кои заеднички нешта се појавуваат во одговорите на прашањата? Како присуството или отсуството на овие заеднички нешта може да го разјасни поставеното прашање во истражувањето? Дали има одговори кои претставуваат отстапување од идентификуваната тема? Ако има, како може да се објасни тоа отстапување? Дали откриените теми или обрасци се слични на дотогашните истражувања? Ако не, што би можело да биде објаснувањето за тоа?

Самото кодирање, како процес на доделување називи на идентификуваните сличности кои оформуваат некаква смислена целина во текстуалниот материјал, може да се направи на два начина: по индуктивен пат, кога кодовите произлегуваат од самиот текст, или дедуктивно, кога тој се сместува во однапред дефинирани категории, обично формирани врз основа на некоја постоечка теорија. Кодовите подоцна се организираат во обрасци, а овие, пак, во теми. Како што беше најавено, ревизијата на организацијата на материјалот во теми е интегрален дел на квалитативната анализа. Таа се прави преку проверка на тоа колку темите навистина добро го рефлектираат кодираниот материјал. Без разлика дали се работи за почетници или за искусни истражувачи, во реализацијата на овој чекор секогаш е добредојдена помош од колеги ангажирани во процесот на осмислување кодови или во класификацијата на материјалот во категориите кои се формираат со кодирањето. Дополнителна поддршка може да биде и консултирањето литература, иако за ова прашање може да се наиде на спротивставени ставови на аналитичари кои тврдат дека увидот во литературата е од помош со оние кои сметаат дека тоа ја контаминира оригиналноста на идеите за тоа кои теми произлегуваат од емпириските податоци.

Ако ревидирањето укаже дека дефинираните теми и обрасци се соодветни, се преземаат следните чекори, а ако не, тогаш се прави редефинирање на темите. Откривањето на новите теми може да го врати процесот и кон ново гледање на материјалот и развивање и нови кодови. Целиот процес е проследен со пишување странични белешки за размислувањата во врска со начинот на кој се поврзани кодовите, заедно со појдовните хипотези и процесот на нивно отфрлање или прифаќање. На страничните белешки може да се гледа како на податоци кои делумно го репрезентираат процесот на рефлексија кој претставува неопходен дел на која било квалитативна анализа, а на кој во извесна смисла може да се гледа како на поддршка кон валидноста на наодите.

Пишувањето на извештајот е паралелен процес со организирањето на материјалот во категории и, слично како и кодирањето, не се изведува целосно во 
еден наврат. Сепак, во моментот кога истражувачот одлучува дека изнашол структура која е задоволителна, треба да произведе и конечен наратив за идентификуваните теми.

Иако често се мисли дека темите „произлегуваат“ од самиот материјал, оваа идеја е тешко одржлива. Колку и да се обидува да направи само редуцирана репродукција на вербалниот материјал, истражувачот, на крајот, веројатно продуцира некаква организација на податоците која неизоставно содржи и интерпретативни делови, ако поради ништо друго, тогаш барем затоа што постојат различни можности за негова категоризација, а тој избира еден од нив како конечен (Cohen, Manion \& Morisson, 2011). Со други зборови, процесот на изведување теми и нивната понатамошна организација во модели, релации или таксономии секогаш содржи елементи на креативност на кои може да се гледа од два аспекта - како на додадена интерпретативна вредност, но и како на проблематична субјективност. Додека работењето со квантитативниот метод обезбедува релативна удобност поради тоа што постојат мошне еднозначно формулирани правила за работа кои би требало да бидат еден вид гаранција за квалитетно изведена научна студија, кога се работи со квалитативните методи, мора да се прифати непријатноста поради значително помалата извесност која ја нудат бројните, а сепак недоволно структурирани препораки за квалитет. Оваа состојба особено важи кога се применува тематската анализа, а таа произлегува токму од карактеристиката која го прави да биде привлечен метод - независноста од конкретна епистемолошка или теориска рамка.

Иако може да се најдат многу препораки за тоа кои критериуми се најважни за да се произведе квалитетен наративен извештај од тематската анализа, генерално, постои согласност дека тој мора да биде логичен, нередундантен и да обезбеди доволно доказен материјал низ избрани цитати за да се демонстрира доминацијата на темите и нивната можна поврзаност. Важно е да се истакне дека овие препораки се само елементарни, бидејќи претставуваат нужен, но не и доволен услов за адресирање на исклучително важното прашање за тоа колку анализата, односно интерпретацијата се повторливи (релијабилни) и кредибилни (валидни).

\section{Видови тематска анализа}

Разгледувањето на различните можни видови тематска анализа во контекст на дискутирањето на критериумите за квалитет на истражувањето се наметнува како нужно затоа што варијациите во нејзиното изведување повлекуваат различни стратегии во неговото обезбедување. Во еден од најцитираните текстови за тематска анализа, Браун и Кларк (Brown \& Clark, 2006) нагласуваат дека тематската анализа е стратегија за барање обрасци во квалитативните податоци, исто како што се, впрочем, и многу други методи кои се ситуирани во различни теориски ориентации: интерпретативна феноменолошка анализа, втемелена теорија, дискурзивна и наративна анализа. Како што веќе беше кажано, она по што тематската анализа се разликува од претходно наведените методи е нејзината ослободеност од специфична теориска ориентација. Оттука, таа е приспособлива и на постпозитивистичките парадигми кои експлицитно или имплицитно инсистираат на 
дедуктивен пристап во категоризацијата (Braun \& Clarke, 2013; Guest, MacQueen, $\&$ Namey, 2012), но и на конструктивистичките, според кои развивањето на кодовите однапред не може да биде третирано како вистинска квалитативна анализа, туку е само еден вид замена за квантитативната анализа на содржина која се сведува на идентификација на фреквенции на категориите. Сепак, дедуктивната стратегија сѐ уште е во употреба и тука е спомената бидејќи таа повлекува сосема поинакви проверки на научната ригорозност во споредба со индуктивната.

Во рамките на индуктивно водената тематска анализа, пак, можни се неколку варијации. Најмалку интерпретативни елементи има во пристапот кој може да се сретне именуван како 'згуснат опис' (Patton, 2002; Wolcott, 1994) односно како 'семантичка тематска анализа' (Boyatzis, 1998). Тoј се дефинира како богата тематска дескрипција на целокупниот збир прибрани податоци во кој не се очекуваат многу интерпретативни елементи. Издвоените теми служат за да се изврши нивна редукција, така што тие претставуваат само рефлексија на содржината и не навлегуваат ниту во длабочина ниту, пак, во некакви обиди да се деконструира и рекомпонира материјалот или, пак, темите да се ситуираат во поширок теориски контекст. Во таа смисла, овој вид индуктивна анализа се третира како квалитативна поради богатството детали кои ги нуди, но од аспект на можноста да се генираат нови сознанија или да се направи некаква социјална трансформација, пристапот е поблизок до квантитативниот метод. ${ }^{1}$

Откривањето на латентните значења на темите подразбира одење чекор подалеку од редуцирана презентација на материјалот и затоа може да се третира како друг, посебен тип тематска анализа, трет во овој конкретен приказ. Поради тоа што бара продлабочен осврт кон податоците, овој вид тематска анализа обично се врши само на еден сегмент од материјалот кој е издвоен како најрелевантен. Затоа, развивањето на темите при преземање ваква тематска анализа, главно (иако не нужно), се потпира на конструктивистичката парадигма и содржи многу елементи на дискурс-анализата (Burr, 1995). Темите претставуваат деконструкција на значењата, кои не произлегуваат директно и исклучиво од вербалниот материјал што се анализира, туку од неговото доведување во врска со поширокиот социјален контекст и односите во него. Типични прашања кои се поставуваат кога се прави ваков вид анализа се: Кои услови довеле до појава на оваа тема? Зошто луѓето зборуваат на овој начин а не на некој друг? Кои се импликациите на оваа тема врз различните социјални групи?

Иако е само во зародиш, треба да се спомене и т.н. синтетичка тематска анализа изведена како аналогија на статистичките метаанализи што се работат во рамките на квантитативниот пристап (Thomas \& Harden, 2007). Таа се прави така што се извлекуваат заеднички теми од повеќе релевантни истражувања правени за

\footnotetext{
${ }^{1}$ Интересно е дека ваквиот начин на анализирање во квалитативната методологија се смета за инфериорен, барем судејќ́ според експлицитните преференции на АПА, која во препораките за квалитет на поднесените манускрипти за едно од најценетите списанија од областа на квалитативната методологија, експлицитно бара студиите да не се сведуваат само на дескрипщија на идентификуваните теми (види на: http://www.apa.org/pubs/journals/qua/?tab=4).
} 
истите истражувани појави, на тој начин што повторно се кодира материјалот од примарните студии, потоа од кодовите се извлекуваат дескриптивни теми, а тие, пак, се соединуваат во интерпретации. Предноста на овој начин на реорганизирање на емпириските податоци од повеќе студии е зголемувањето на можноста за генерализирање на наодите, што во споредба со ограничените можности за изведување генерализации на поединечните истражувања претставува сериозна придобивка. Обезбедувањето ригорозност кај овој вид студии е двоен предизвик бидејќи тие се потпираат на секундарни извори како емпириски материјал.

Најнакрај, како посебни видови тематска анализа може да се третираат сите теориски засновани облици кои се изведуваат врз основа на правилата што произлегуваат од школата односно учењето, како што се херменевтичката, феноменолошката тематска анализа или тематската анализа базирана на втемелена теорија. Разликата на генеричките облици на тематска анализа и таа која потекнува од втемелената теорија, главно, се сведува на тоа дека податоците кај втората се прибираат паралелно со анализата и тоа според методот на теориско заситување, па затоа се многу помалку погодни за споредба на два корпуса податоци, особено ако едниот е претходно постоечки (прибиран во друг наврат или дури и од друг автор). Херменевтичката анализа, пак, битно се разликува од генеричката тематска анализа од аспект на тоа дека таа го зема предвид поширокот контекст во кој биле прибирани податоците, па поради тоа е многу помалку соодветна за опис кој е фокусиран само на личните значења кој изнесениот вербален материјал го има за испитаниците. Предноста на теориски засновата тематска анализа од аспект на обезбедување валидност е во тоа што секоја ориентација има повеќе или помалку елаборирани насоки за тоа како таа се обезбедува во нејзините рамки.

\section{Евалуација на квалитетот на изведената тематска анализа}

Потребата да се прави разлика меѓу наведените стратегии во правење тематска анализа произлегува од мошне релевантното методолошко прашање за проверка на ригорозноста во спроведувањето на анализата на податоците. Познато е дека за разлика од квантитативниот метод, квалитативниот се соочува со многу предизвици од аспект на обезбедување објективност, релијабилност и валидност и тоа почнувајќ од фактот дека за спроведување на анализата не постојат униформирани алатки како што се техниките на статистичка обработка, до тоа дека нема единствена епистемолошка платформа која е општоприфатена меѓу истражувачите. Тоа не значи дека нема елаборирани препораки ${ }^{2}$ за тоа како да се спроведе соодветна квалитативна анализа, но тие не се ни оддалеку толку цврсти, а уште помалку монолитни правила, како што се тие според кои се раководат квантитативните истражувања.

\footnotetext{
${ }^{2}$ На пример, барањата за квалитет на квалитативните истражувања на Британската психолошка асоцијација и Американската психолошка асоцијација се лесно достапни на интернет и претставуваат основни услови за објавување на студиите во списанијата кои се поддржани од нив.
} 
Речиси не постои автор кој се занимава со проблемите на квалитативната методологија а кој не се согласува со аргументите за тоа дека е неопходно да се прави разлика во дефинирањето на тоа што се подразбира под критериумите за квалитетно (ригорозно) спроведено истражување кога тоа се прави со квалитативен наспроти квантитативен метод (Miyata \& Kai, 2009, Whittemore, Chase, \& Mandle, 2001), наспроти ризикот поврзан со тоа вториот да биде прогласен за ненаучен. Ова е дотолку повеќе што сѐ уште не постои општа согласност за тоа кои се аналогните начини на евалуација на квалитетот, па дури ни кои се заменските називи за нив. Сепак, судејќи по застапеноста и цитираноста, работата на Линколн и Губа (Lincoln \& Guba, 1985) за определување критериумите за проверка на ригорозноста и квалитетот на истражувањето може да се смета за еден вид класика. За да се направи јасна дистинкција, тие инсистираат на промена на називите на критериумите за квалитет. Така, за релијабилноста се користи терминот постојаност, конфирмабилноста е замена за објективност, наместо екстерна валидност се користи терминот трансферабилност, а наместо интерна валидност - кредибилност. Иако постојат бројни препораки за проверка и постигање на сите барани аспекти на квалитет - објективност, релијабилност, генерализибилност и валидност, овде фокусот ќе биде задржан само на двата од нив кои се сметаат за клучни и тоа само во контекст на спроведување тематска анализа.

Релијабилноста на истражувањата во квантитативната методологија најчесто се дефинира како степен до којшто под слични околности и со исти методи се добиваат слични наоди (Traub, 1994). ${ }^{3}$ Јасно е дека релијабилноста дефинирана како стабилност на истражуваните појави не може да се примени, барем не во огромното мнозинство случаи, затоа што квалитативните истражувања по дефиниција се вршат за феномени кои се неповторливи и контекстуално зависни, па затоа мерките што се преземаат, главно, се насочени кон проверка на соодветноста н класификацијата на материјалот.

Доколку тематската анализа се изведува по дедуктивен пат, мерките кои се преземаат за да се обезбеди постојаност на класификацијата се сведуваат на фокусирање на вниманието кон јасноста на правилата за класификација и дефинирање на категориите (Krippendorff, 2004). Таа се проверува со повторување на процесот од страна на самиот истражувач (интрасубјективна согласност) или преку споредување на компатибилноста со која категоризацијата на истиот материјал во истите однапред дефинирани категории ја прават двајца или повеќе истражувачи (интерсубјективна согласност). ${ }^{4}$ Кај индуктивната анализа, процесот е посложен,

\footnotetext{
${ }^{3}$ Кирк и Милер (Kirk \& Miller,1986) зборуваат за три типа релијабилност: квиксотична, синхронична и дијахронична. Синхроничната релиајбилност, која подразбира сличност на опсервациите во рамките на даден временски период, и дијахроничната која значи стабилност или неменливост на опсервациите низ временски период, не е применлива на квалитативниот метод заради претпоставената потреба од неменливост и на проучуваните појави и на контекстите.

${ }^{4}$ Логиката на овие начини на обезбедување на релијабилноста не е прифатена без резерва. Критиката на овој начин на резонирање е сконщентрирана на идејата дека повеќ истражу-
} 
бидејќ ревизијата од страна на друг(и) истражувач(и) мора да вклучи систематско споредување на транскриптите со развиените кодови и работни хипотези, па дури и проверка на тоа колку материјалот што е кодиран претставува фер репрезентација на целокупната содржина (Schwandt, 1997).

Проверката на кредибилноста на анализата е уште посложен процес, а сложеноста, пред сѐ, е одраз на бројноста на начините на кои таа се дефинира во рамките на различни парадигми и ориентации. Веќе беше објаснето дека за разлика од квантитативните истражувања коишто потекнуваат од една епистемолошка парадигма (позитивизам), квалитативните истражувања се надоврзуваат на неколку различни платформи. Тука, само како илустрација ќе бидат наведени неколку различни гледишта во рамките на квалитативната методологија за тоа како се обезбедува идеалот за квалитет на истражувањето кој во квантитативната е познат како интерна валидност.

Истражувачите коишто работат во рамките на конструктивистичката традиција бараат од истражувањето: да може да опфати различни перспективи, да ги идентификува и дискутира можните извори на пристрасност, да ја одразува автентичната перспектива на испитаниците, да овозможува продлабочено разбирање на перспективата на испитаниците или да придонесува кон воспоставување општествен дијалог (Whittemore et al., 2001). Ако истражувањето, пак, произлегува од критичката теорија, тоа ќе биде проценувано од перспектива на следниве критериуми: степен во којшто се идентификувани изворите и природата на општествените нееднаквости, степен во којшто нееднаквоста и неправдите се направени повидливи, умешност на истражувачот да ја претстави перспективата на помалку моќните општествени групи, но и да ги идентификува стратегиите за општествена промена. Треба да се има на ум дека речиси секоја поединечна дефиниција на кредибилноста повлекува барање на посебна стратегија која се презема за таа да се докаже. Така, на пример, кога кредибилноста на истражувањето се дефинира како автентичност во рефлектирањето на животното искуство и перцепциите на испитаниците, тогаш таа се проверува на тој начин што се бара од самите испитаници да потврдат дали интерпретацијата веродостојно го одразува нивното искуство. Приврзаниците на идејата за трансформациска валидност на истражувањата го вреднуваат истражувањето низ перспектива на тоа колку интерпретациите придонесуваат кон постигнување социјална правда, подлабоко разбирање и пошироки визии за положбата на луѓето во заедницата (Kvale, 1995). Слично, иако од друга појдовна основа, која произлегува од потребите на практичарите во различни области, се предлага кредибилноста да се проверува преку апликабилноста на истражувањето (Sandelowski, 1997). Тоа би значело дека ако наодите се покажат како вредни за унапредување на праксата во дејноста, тогаш тие се сметаат за валидни.

Јасно е дека проверката на кредибилноста на истражување засновано на тематската анализа, доколку таа е работена низ призма на различните ориентации, ќе биде онаква каква што наложува дефиницијата предвидена со пристапот. Во

вачи може да развијат идентична категоризација, а таа да биде подеднакво проблематична репрезентација на материјалот (на пр. Loffe \& Yardley, 2004). 
последниве две декади, сѐ почесто се забележуваат обиди да се воведе практиката на т.н. мултиперспективна или плуралистичка анализа за докажување на кредибилноста, што во контекст на проверката на соодветноста на тематската анализа би значело таа да се прави со користење на повеќе различни интерпретативни пристапи - феноменолошки, херменевтички и низ перспектива на втемелената анализа (Frost, 2013). Колку е поголема сличноста на издвоените теми со помош на секоја од различните стратегии, толку наодите може да се сметаат за покредибилни.

Сепак, најгорливото прашање - начинот на евалуација на квалитетот на тематската анализа кога таа е генеричка, односно слободна од експлицитната врска со некоја платформа или ориентација, не се решава ниту со овој пристап. Со оглед на тоа дека токму ваквиот начин на користење на тематската анализа најмногу се користи, особено во комбинираните истражувања, важноста на адресирање на овој проблем не дозволува тој да биде игнориран. За жал, прегледот на литература укажува на една малку парадоксална ситуација: речиси не постои текст во кој најексплицитно не се потцртува важноста на обезбедување веродостојност на анализата низ нејзина ригорозна проверка (на пр. Graneheim \& Lundman, 2004; Pyett, 2003; Thomas \& Magilvy, 2011), но тие препораки се само декларативни и не се проследени со упатства за чекорите што треба да се преземат во врска со тоа, а уште помалку со експлицитно барање за содржините на приказот на направената ревизија.

Врз основа на увидот во релевантните референци, може да се заклучи дека постојат неколку почесто споменувани алатки за евалуација на кредибилноста. Најпрво, при развивањето на категориите, мора да се води сметка за обезбедување соодветен систем кој е истовремено интерно конвергентен, екстерно дивергентен и инклузивен. Интерната хомогеност значи дека содржините сместени во иста категорија мораат да имаат нешто што ги обединува, а е од значење за понатамошната интерпретација, додека екстерната хетерогеност значи дека она што е обединувачко за конкретната категорија е битно различно од она што е обединувачко за друга (Elo, Kääriäinen, Kanste, Pölkki, Utriainen \& Kyngäs, 2014). Системот на развиени категории е соодветен доколку тој има задоволувачки степен на инклузивност, што значи дека откако содржината ќе се распореди по категориите, само незначителна количина материјал ќе остане надвор од зададените категории. Пожелно е истовремено да се демонстрира и дивергентноста на категоризацијата. Тогаш кога категоризацијата е заситена и додавањето нови категории ќе биде одвишно, можеме да кажеме дека сме обезбедиле збир од категории коишто задоволуваат во поглед на ова барање. Понатаму, целата категоризација мора да се направи со информиран увид во контекстот (Vaismoradi, Turunen, \& Bondas, 2013).

Кредибилноста може значително да биде поддржана со илустрирање на наодите со добро избрани изворни цитати од испитаниците. Иако вметнувањето релевантни искази претставува основно барање за спроведување добра анализа, треба да се внимава на тоа да не се западне во стапицата дека поддршката во цитатите е сама по себе доволен доказ за соодветноста на темата. Ова доаѓа оттаму што некогаш се дозволува ситуација во која темите се извлекуваат директно од 
цитатите, така што сличноста меѓу нив е сосема неважна за квалитетот ако се земе предвид дека со користење на таков пристап, анализа воопшто и не е направена. Иако се претпоставува дека ретко некој така постапува, не е лошо да се нагласи дека едноставното извлекување на највпечатливите цитати и нивно третирање како теми претставува само проблематичен обид да се обработат податоците, ама не и нивно вистинско анализирање.

Неизоставен дел на извештајот за проверката на кредибилноста на анализата е авторефлексивниот осврт, бидејќи се верува дека увидот во начинот на резонирање, личните и професионалните ориентации или дури и различни контекстуални фактори може да ги изнесат на површина потенцијалните пристрасности во интерпретацијата. Рефлексивноста, како и да е дефинирана, подразбира обезбедување увид во критични делови од истражувачкиот дневник и во белешките и работните хипотези генерирани за време на обработката на материјалот (Koch et. al., 2014; Saldana, 2009). Паралелно, секогаш се препорачува авторот да ги изнесе на површина слабите точки на истражувањето и дилемите поврзани со генерирањето на главните теми и обрасци.

Некои автори сметаат дека вклучувањето шематски прикази, исто така, може да придонесе во подобрување на можноста да се евалуира кредибилноста, особено ако односите меѓу темите претпоставуваат некаква хиерархија или друг вид однос кој не е линеарен. Шемите неретко даваат појасен увид во тоа како се одвивала анализата отколку кога се презентира само наративниот извештај (Alhojailan, 2012; Elo et.al., 2014).

Последната препорака за обезбедување кредибилитет е да се овозможи верификација на направената анализа од страна на учесниците во истражувањето. Проверката на кредибилноста преку споделување со самите испитаници се прави и кога анализата е генеричка, иако постојат автори кои сметаат дека овој процес најчесто погрешно се разбира, па оттука произлегуваат дискусиите за тоа колку ваквиот начин на верификација на наодите помага за валидноста или многу повеќе може да се третира како добра практика од аспект на етичност во третманот на испитаниците (Braun \& Clarke, 2006). Барањето за претпазливост во врска со ваквиот начин на валидација е поврзано со прашањето дали испитаниците како извор на податоци се инволвираат во проверка на интерпретациите, како што вообичаено се прави, или во еквивалентноста на значењето на нивните искази со тоа како истражувачот ги разбира. Првиот начин подразбира да се споделат наодите, што може да биде мошне збунувачки за испитаниците поради слабата врска меѓу изворните податоци и синтетизираните наоди, па затоа е токму тој кој се проблематизира. Вториот, пак, се сведува на барање за чести резимирања и парафразирања при водење на интервјуто (или фокус-групата) за да се провери колку добро е разбран изворниот материјал, а не да се потврди колку е соодветна интерпретацијата или да се види дали можеби е поадекватно некое алтернативно објаснување. 


\section{Заклучни согледувања}

Флексибилноста и едноставноста во примената ја прават тематската анализа еден од најфаворизираните методи на анализа на квалитативни податоци и покрај тоа што сѐ уште не постои ниту најава за можност за конвергенција на различните ставови околу тоа како да се провери соодветноста на тоа како е изведена. Дополнителна добра страна на тематската анализа е дека е лесно читлива и за општата популација која е едуцирана, односно не бара висока стручност за да може да се следи. Згора на тоа, таа овозможува лесно споредување во рамките на податоците и со неа може да се изведе и социолошка и психолошка интерпретација на податоците. Оттука, исклучително е корисна за извештаи од евалуации или акциски истражувања.

Пред да се одлучи дали ќе ѝ се даде предност врз основа на нејзините бројни позитивни страни, треба да се има на ум дека таа не е секогаш најсоодветниот избор. Она што дополнително ја прави проблематичен метод, ако се изземе дискутираната можност таа да биде направена врз основа на прелабави или дури и непостоечки критериуми за валидност, е и нејзината слаба моќ да го фокусира истражувачот кон начинот на кој треба да го одговори истражувачкото прашање. Најнакрај, треба да се забележи и тоа дека, како стратегија, генеричката тематска анализа има мошне лимитирана интерпретативна моќ (Braun \& Clarke, 2006) и може да биде преробусна за анализа кога е неопходно да се направат фини разлики во добиените податоци.

Со оглед на досегашното темпо на развој на овој метод кај нас, тешко е да се верува дека на пазарот набргу ќе може да се најде употреблива верзија на софтверски пакет за квалитативна анализа на податоците. Сепак, вреди да се спомене дека современите софтверски решенија за квалитативна анализа (како што се NVivo, QDA miner, MAXQDA, Dedoose и сл.) насокоро ќе отворат повеќе простор за сигурност дека освен врз ефикасноста во работењето, ке имаат ефект и врз подобрување на постојаноста и кредибилноста на анализата. 


\section{Литература}

Alhojailan, M. I. (2012). Thematic analysis: a critical review of its process and evaluation. West East Journal of Social Sciences, vol. 1/1, 39-47.

Attard, A. and Coulson, N.S. (2012). A thematic analysis of patient communication in Parkinson's disease online support group discussion forums. Computers in $\mathrm{Hu}$ man Behavior 28(2), 500-506.

Boyatzis, R.E. (1998). Transforming qualitative information: thematic analysis and code development. London: Sage Publications.

Braun, V. \& Clarke, V. (2006). Using thematic analysis in psychology. Qualitative Research in Psychology. 3(2), 77-101.

Braun, V. \& Clarke, V. (2013). Successful qualitative research: A practical guide for beginners. London: Sage.

Buetow, S. (2010). Thematic analysis and its reconceptualization as 'saliency analysis'. Journal of Health Services Research \& Policy, 15(2), 123-125.

Burr, V. (1995). An introduction to social constructionism. London: Routledge.

Cohen, L., Manion, L. \& Morrison, K. (2011). Research Methods in Education. 7th ed. Routledge.

Elo, S., Kääriäinen, M., Kanste, O., Pölkki, T., Utriainen, K. \& Kyngäs, H. (2014).. Qualitative Content Analysis: A Focus on Trustworthiness. SAGE Open, January-March, 1-10. DOI: 10.1177/2158244014522633

Frost, N. (2013). Looking forward. In N. Frost (Ed.), Qualitative Research Methods in Psychology: Combining Core Aprroach. Berkshire: Open University Press, 185 $-192$.

Graneheim, U. H., \& Lundman, B. (2004). Qualitative content analysis in nursing research: Concepts, procedures and measures to achieve trustworthiness. Nurse Education Today, 24, 105-112.

Guest, G., MacQueen, K. M., \& Namey, E. E. (2012). Applied Thematic Analysis . Thousand Oaks, CA: Sage.

Krippendorff, K. (2004). Content analysis: An introduction to its methodology (2nd ed.). Thousand Oaks: Sage.

Kirk, J. M., \& Miller, M. L. (1986). Reliability and validity in qualitative research. Beverly Hills, CA: Sage.

Kvale, S. (1995). The Social Construction of Validity. Qualitative Validity, 1/1, 19-40.

Lincoln, Y. S. \& Guba, E. G. (1985). Naturalistic Inquiry. London: Sage Publications.

Loffe, H. \& Yardley, L. (2004). Content and thematic analysis. In: Marks D.F. \& Yardley, L. (eds). Research Methods for Clinical and Health Psychology (56-69). London: Sage Publications.

Lynn C. Koch, L., Niesz, T. \& McCarthy, H. (2014). Understanding and Reporting Qualitative 
Research: An Analytical Review and Recommendations for Submitting Rehabilitation Counseling Bulletin, 57(3), 131-143.

Morse, J. M., Barrett, M., Mayan, M., Olson, K., \& Spiers, J. (2002). Verification strategies for establishing reliability and validity in qualitative research. International Journal of Qualitative Methods 1 (2), 1-19.

Miyata, H. \& Kai, I. (2009). Reconsidering Evaluation Criteria for Scientific Adequacy in Health Care Research: An Integrative Framework of Quantitative and Qualitative Criteria. International Journal of Qualitative Methods, 8(1), 64-75.

Patton, M.Q. (2002). Qualitative research and evaluation methods. 3rd ed. Thousand Oaks: SAGE.

Percy, W. H., Kostere, K., \& Kostere, S. (2015). Generic qualitative research in psychology. The Qualitative Report, 20 (2), 76-85.

Pyett, P. M. (2003). Validation of qualitative research in the "real world." Qualitative Health Research, 13, 1170-1179.

Saladana, J. (2009). The Coding manual for Qualitative Researchers. Thousand Oaks, California: Sage Publications.

Sandelowski, M. (1997). "To be of use": Enhancing the utility of qualitative research. Nursing Outlook, 45(3), 125-132.

Sandelowski M. (2010). What's in a name? Qualitative description revisited. Research in Nursing \& Health, 33, 77-84.

Snelson, S. L. (2016). Qualitative and Mixed-methods in Social Media Research. International Journal of Qualitative Methods, January-December, 1-15 DOI: 10. $1177 / 1609406915624574$

Schwandt, T. A. (1997). Qualitative inquiry: A dictionary of terms. Thousand Oaks, CA: Sage.

Thomas, J. \& Harden, A. (2007). Methods for Research Synthesis Node, Evidence for Policy and Practice Information and Coordinating Centre, Working Paper Series.

Thomas, E., \& Magilvy, J. K. (2011). Qualitative rigour or research validity in qualitative research. Journal for Specialists in Pediatric Nursing, 16, 151-155.

Traub, R. E. (1994). Reliability for the Social Sciences: Theory and Applications. Thousand Oaks: Sage.

Vaismoradi, M., Turunen, H. \& Bondas,T. (2013).Content analysis and thematic analysis: Implications for conducting a qualitative descriptive study. Nursing and Health Sciences, 15, 398-405.

Wolcott, H. (1994). Transforming Qualitative Data: Descriptions, Analysis and Interpretation. London: SAGE.

Whittemore, R., Chase, S. K., \& Mandle, C. L. (2001). Validity in qualitative research. Qalitative Health Research, 4, 522-537. 
Nikolina KENIG

\section{THEMATIC ANALYSIS: POSSIBILITIES FOR EVALUATION OF RESEARCH QUALITY}

\section{Summary}

Thematic analysis is widely-used qualitative analytic method within psychology, both in primary qualitative and mixed-method research. This paper outlines what thematic analysis is and how it is used in relation to different epistemological and ontological positions and presents the important features of the different types of thematic analysis including the generic ones. It discusses the necessity of reviewing the process in a systematic way and explains the strategies for assuring stronger reliability (dependability) and validity (credibility) of findings generated by this approach. By highlighting the advantages and weaknesses of thematic analysis, the author concludes with suggesting criteria when this approach is the most suitable solution for data analysis. It is concluded that although thematic analysis as one of the most useful methods for qualitative research its use is limited to research questions that do not require narrower focus and fine nuances in the analysis.

Keywords: THEMATIC ANALYSIS, QUALITATIVE RESEARCH, CREDIBILITY 